\title{
Drivers of Profitability in Pakistan Stock Exchange (PSX) through Du-Pont Equation
}

\author{
Adees Ahmed \\ Research Scholar \\ Karachi University Business School, University of Karachi, Pakistan \\ Dr. Danish Ahmed Siddiqui \\ Associate Professor \\ Karachi University Business School, University of Karachi, Pakistan
}

\begin{abstract}
This research paper aims to investigate the impact of different components of Du-Pont model on firms' profitability (1) on stand-alone basis, and (2) in the presence of different macro-economic factors. These components include profit margin, total assets turnover and financial leverage. Financial information from five different sectors of Pakistan's economy comprising of automobile, cement, fertilizer, oil and gas and power \& distribution was collected for years ranging from FY2011 to FY2017. Few macro-economic factors such as Exchange Rates, GDP, Inflation, and Interest rates are also taken into consideration. In this paper, LS and GMM regression models have been implied on Du-Pont model (financial ratios) and the results indicate that profit margin is a major driver of profitability amongst all the other factors of Du-Pont across various economic sectors of economy of Pakistan. Hence, the business managers should exert more focus on adjusting the micro-economic factors, perhaps profitability, while adapting to macro-economic factors
\end{abstract}

Keywords: Du-pont, Profitability, Pakistan, GMM, Leverage, Turnover, Sectors

DOI: $10.7176 /$ RJFA/10-10-16

Publication date:May $31^{\text {st }} 2019$

\section{INTRODUCTION}

\subsection{BACKGROUND TO THE STUDY}

A business is explained as "any activity that is performed to earn profit", now the point to ponder is that how profitability of the organization can be determined, which profitability measure shall be adapted, and how interorganization and intra-organizational horizontal and vertical analysis shall be conducted to evaluate the overall performance and profitability of the firm viz-a-viz the entire industry. The answer to all these questions calls for profitability analysis which comes under the ambit of "analysis of financial statements", where comparisons of profitability are being made between firms of the same industry.

The primary goal of any firm is to generate an optimal level of profit, without which the company might not able to sustain its footings in the long-run. Although the terms profit and profitability are accounting metrics gauging the financial success of the company, but distinct differences lie between the two (HORTON, 2019). "Profit" is simply an "absolute number" that is calculated by subtracting expenses from the income, irrespective of company's size, scope, nature and the industry in which it operates. Contrarily, "profitability" is a "relative" metric that measures the firms profit generation ability and operational efficiency that is, profitability does account for factors such as size, nature, and scope of the company while determining the return generated by the company on investment/resources employed (Hofstrand, 2009). Thus, it is imperative for the stakeholders (management, investors, analysts etc.) to be cognizant of profitability of the firm in order to assess the financial well-being of the company with respect to its competitors.

Organizations must yield positive returns on equity (ROE) to ensure the financial viability of long-term goals. It does not only benefit the organization to restructure capital mix, finance growth, induce benefits to shareholders but also provide them shield against issues such as liquidation, market-share convulsion and prevents them from becoming a target to merger, acquisitions and other regulatory penalties (Turner, Broom, Elliott \& Lee, 2015).

Historically, the profitability of the organization was assessed by the management and other shareholders on the basis of simple ratios such as Gross-Profit To Net Revenue, Net Operating Profit To Net Revenue, Return On Capital Employed, Net Profit To Net Revenue, and Return on Owners' Equity were the chief metrics ("Profitability Analysis", n.d.).

Later on, the utility of DuPont analysis as a measure of assessing ROE and ascertaining the quality of earning has convinced the analysts to capitalize upon this model. Decomposition of ROE into three distinct segments, profit margin, assets turnover and leverage / capital structure do not only reveals the driver of profitability but also allow firm-specific comparison over a passage of time (Turner, Broom, Elliott \& Lee, 2015).

The well renowned and famous Du-Pont equation in profitability analysis explains the drivers of profitability in detail with three drivers which are asset turnover, financial leverage, and profit margin. The Du-Pont model is 
a model used to do profitability analysis of the companies by the help of their previous performance given in the financial statements. By the help of the three key indicators (asset turnover, financial leverage, and profit margin) of Du-Pont equation, an analyst can easily explains the company's position that it is earning good profits or not.

Succinctly, the DuPont model enables the analyst to ascertain whether the overall profitability of a firm is (1) emanating from the firm's income minus expenses (profit margin), (2) a result of effective and efficient use of organization's asset (ATO), (3) stemming from the mix equity and debt employed by the company (capital structure), or any combination of these factors (Turner, Broom, Elliott \& Lee, 2015).

Although the traditional DuPont Model and its modifications clearly illustrate that Company's Return on Equity can be identified on the basis of three factors comprising of Profit Margin, Total Assets Turnover and Equity Multiplier; however, analysts, investors and researchers are still trying to identify the most impactful factor of profitability indicator i.e. Return on Equity (Mubin, Iqbal \& Hussain, 2014). This research paper mainly focuses the impact of key indicators of Du-Pont equation on the profitability of the firms in the presence of macroeconomic factors (exchange rates, GDP, inflation and interest rates) to ascertain the most impactful driver of profitability in five different sectors of Pakistan's economy comprising of automobile sector, cement sector, fertilizer sector, oil \& gas sector and power generation \& distribution sector. The outcomes of this paper can be utilized by investors in assessing how the operational efficiency, profitability and capital structure of the organization of each of the five sectors of economy can impact the ROE of the company.

Moreover, it will serve as a platform for other researchers to perform inter-industry and intra-industry analysis identifying the most powerful determinants of ROE on stand-alone basis as well as in the presence certain macroeconomic and seasonal factors.

\subsection{GAP ANALYSIS}

Soliman (2004) have identified that industry-specific DuPont multiplicative components plays more vital role in driving the profitability as compared to macro-economic factors, thereby, suggesting that industry-specific ratios have increased validity. Similarly, Majed et al (2012) revealed that the company's performance in terms of ROA, ROE and ROI cumulatively results in robust and positive relationship with share prices; however, the role of macro-economic conditions was entirely neglected in this research. Moreover, the findings of this research unveiled the individual effect of ROA, ROE and ROI; and identified that ROA and ROI has positive but relatively low relationship with market share-price; but failed to pinpoint the individual relationship between ROE and market share-price. Saleem Q and Naseem MA (2012) theorized that inverse relationship exists between leverage and profitability in oil and gas sector. However, their findings were not conclusive enough to depict a positive relationship between financial leverage and profitability. Additionally, they attempted to address their query regarding the riskiness of investment in highly leveraged company in terms of return on equity and came across the fact that highly leveraged firms were less risky in both market-based and accounting-based measures. Saleem $\mathbf{Q}$ and Rehman R (2011) tried to reveal the relationship between liquidity and profitability in case of oil and gas companies of Pakistan with data of 2004 to 2009. Their results show that there is a significant impact of only liquid ratio on ROA while insignificant on ROE and ROI; the results also show that ROE is no significant effected by three ratios current ratio, quick ratio and liquid ratio while ROI is greatly affected by current ratios, quick ratios and liquid ratio. Benjamin, S. J., Mohamed, Z. B. and Marathamuthu, M. S. (2018) have utilized the DuPont framework to ascertain the impact of DuPont component on firms dividend policy in Malaysian economy. This study finds both PM and ATO to strongly explain contemporaneous dividends. The decomposition of return on net operating assets (RNOA) into PM and ATO also improves the explanatory power of dividends. The results of the predictive model show that PM and ATO are useful in predicting the propensity of firms to pay dividends. The results of the change dividend model, however, do not provide any significant results for PM and ATO. Sheela, S. C. and Karthikeyan, D. K (2012) demonstrated the comparison of performance and condition of Indian pharmaceutical company against its competitors with the help of profitability ratios like ROI and ROE. The DuPont analysis was made for the top 3 most profitable pharmaceutical ventures operating in India emphasized that absolute measurements are not relevant every time. Therefore, to have a common basis of comparison between several companies and to compose ranks the relative sizes for measuring efficiency are necessary when calculating the ratio. Mubin, Iqbal \& Hussain (2014) identified the most consistent or volatile DuPont component among profit margin, total assets turnover and equity multiplier in Fuel and Energy Sector, Chemicals Sector, Cement Sector, Engineering Sector, Textiles Sector and Transport and Communication Sector of KSE 100 index. Their research discovered that return on asset is the most influential component of DuPont framework that determines the profitability of companies operating in Pakistan. Nevertheless, the analysis was conducted on stand-along basis, without taking into consideration the macro-economic factors - making the results of this research a bit dubious. Most of the researches based on DuPont framework were aimed to find out the most significant component of profitability of a particular company or industry on stand-alone basis, that is, without accounting for macroeconomic factors and without making intra-industry comparisons. On the contrary, this research has not only attempted to cover the entire economy of Pakistan (by considering companies from five different sector) but has 
also tracked the impact of DuPont components in the presence of macro-economic factors.

\subsection{RESEARCH OBJECTIVES}

To determine the driver of profitability among the three key factors of the Du-Pont equation (with and without macro-economic factors) in Pakistan stock exchange by targeting five different sectors including automobile sector, cement sector, fertilizer sector, oil and gas sector and power generation and distribution sector.

The above research problem is investigated by the following research questions:

Which of the three factors of Du-Pont equation has the most prominent impact on the profitability of firms operating in Pakistan without considering the macro-economic factors?

Which of the three factors of Du-Pont equation has the most prominent impact on the profitability of firms operating in Pakistan in the presence of macro-economic factors?

\section{LITERATURE REVIEW}

The Du-Pont analysis was created by E.I. du Pont de Nemours in 1919. The Du-Pont analysis is one of the oldest and easiest methodology that provides good understanding of ratios and their change. The general profitability in this equation is signified by asset turnover and profit margin. It may considered as a complicated approach because the elements required for the analyses are taken from both the balance sheet and the income statement. The key variable in the du-Pont equation is return on equity which is considered as the strong indicator of company's wealth. The advanced studies started to explore the phenomena of ROE (return on equity) to identify the most important characteristic of roe. Lambert and Larcker (1987) studied the relationship among CEOs cash compensation and $\mathrm{ROE}$ and stock returns performances. As a result of this study it was showed that, there is strong relationship among CEOs cash compensation and stock returns and less relation with ROE.

The most significant part of Du-Pont analysis is ROE. For financial ratio analysis, Du-Pont analysis is mostly used by professionals (Bernstein and Wild 1998; Revsine, Collins and Johnson 1999; Stickney and Brown 1999).

Leisz T. J. and Maranville S. J. (2008) have assessed that the profitability of ventures can be determined by only simple calculation while analysis is based on "Du Pont model". They also emphasized that the decisions based on these calculations (Ratio and Dupont analysis) have the potential to enable the firms to take proactive measures that will yield higher profit / return. They further stressed upon a fact that valuable insights leading to prosperous decisions can be achieved even while relying on basic Du-Pont Model (culminating in ROA), but the utilization of extended versions does not only allow financial managers to accentuate upon the other components associated with the determination of ROE but also enables them to come up with such decisions which maximize the wealth of the stakeholders (Pratt \& Hirst 2008; Palepu \& Healy 2008; Soliman 2008; and Nissim \& Penman 2001).

Saleem Q and Rehman R (2012) in their research paper "Impact of Liquidity Ratio on Profitability (Case of Oil and Gas Companies of Pakistan)" have hypothesized the impact of leveraged oil and gas companies on their profitability. Their outcomes revealed that no positive relationship exists between financial leverage and profitability, and highly leveraged companies are less susceptible to risks in terms of accounting and market-based measures.

Moreover, Soliman (2004) in his article has unveiled the fact that the results based on industry-specific DuPont multiplicative components are far more useful than economy-wide components, highlighting that industryspecific ratios are more significant.

Saunders (2000) has devised a vibrant financial analysis model for financial institutions lying on the fundamental concepts of return on equity, return on investment and DuPont system. Return on equity model is based on equity multiplier, total asset turnover and net profit margin. Profit Margin is a measure that enables the evaluation of income and financial performance of the company whereas total asset turnover and equity multiplier addresses the left-hand side and right-hand side of company's balance sheet, that is, assets and liabilities + equity. Brigham and Houston, (2001) defines DuPont Model as a tool that depicts the relationship between enterprise's balance sheet, and income statement and enables the management to formulate strategies augmenting the company's ROE.

\section{Conceptual Framework}

Profitability: The term profitability refers to the firm's profit margin, that is, net income/total revenue. Investigation of profit margin enables the examiners to decide the part of income that streams to "the primary concern" for each dollar of income. High edges are regularly connected with associations that are engaged with rendering specialty administrations/items, have stringent authority over its cost structure (economies of scales or powerful utilization of benefits), and the ones appreciating monopolistic economic situations. Analysis of profit margin allows the analysts to determine the portion of income that flows to "the bottom line" for every dollar of revenue. High margins are often associated with organizations that are involved in rendering niche services / products, have stringent control over its cost structure (economies of scales or effective use of assets), and the ones 
enjoying monopolistic market conditions.

Efficiency: Asset Turnover Ratio is a metric most commonly used for measuring firm's efficiency by dividing total sales with total assets. It allows the users of financial information to assess how effectively the firms is capitalizing its assets in generating profitability. Those sectors of economy that are closely monitored and regulated by central authorities or the one where cut-throat competition prevails, that is the segments where pricing environment is extremely competitive, one of the key way of generating profits and yielding higher ROE is efficacious use of company's assets. It enables the clients of money related data to survey how adequately the organizations is promoting its benefits in producing gainfulness. Those parts of economy that are intently checked and controlled by focal specialists or the one where ferocious challenge wins, that is where evaluating condition is very aggressive, one of the key method for producing benefits and yielding higher ROE is viable utilization of organization's advantages.

Capital structure: The Company must be having optimal capital structure as the use of debt has the tendency of magnifying ROE either positively or negatively. Since, the company can finance its operations / assets either through debt or equity; therefore, the firms have to make a decision that the proportion of these two shall be such that the company must be able to generate the most out of its combination. The third component of DuPont model pertains to measurement of company's financial leverage by means of equity multiplier. It is a financial ratio determined by dividing a company's total asset value by total net equity.

ROE = Profit Margin (Profitability) * Asset Turnover (Efficiency) * Equity Multiplier (Capital Structure) Later on, Hawawini and Viallet (1999) realized that the DuPont does not account for the impact of tax and financial cost and has gave the concept of "really" modified DuPont model as shown below:

ROE $=($ EAT $/$ EBT $) \times($ EBT $/$ EBIT $) \times($ EBIT/Sales $) \times($ Sales $/$ IC $) \times(I C / E)$

Where:

RoE $=$ Return on Equity,

EAT $=$ Earnings after Tax,

EBT $=$ Earnings before Tax

$\mathrm{EBIT}=$ Earnings before Interest and Tax,

IC = Invested capital $=$ Cash + Working Capital Requirement + Net Fixed Assets.

Through this amendment they emphasized the fact that the annual financial statements of the firms depict information critical to creditors and tax collectors only and do not always provide information to manager for operating and financial decisions (Brigham and Houston, p. 52). Hence, they attempted to restructure the traditional balance sheet into a "managerial balance sheet" which is "a more appropriate tool for assessing the contribution of operating decisions to the firm's financial performance" (Hawawini and Viallet, p. 68). The principal idea behind this restructuring is that the revised balance sheet is based on the concept of "invested capital" in lieu of total assets, and the concept of total liabilities and owners' equity has been replaced with "capital employed". The treatment of the short-term "working capital" accounts is the distinguishing feature of restructured balance sheet as the managerial balance sheet uses "working capital requirement" as a part of invested capital (Liesz, n.d.).

Really modified DuPont model determines ROE by evaluating the impact of firm's:

1. Operating decisions with the help of (a) operating profit margin: (EBIT / sales) and (b) capital turnover: (sales / invested capital),

2. Financing decisions by determining (a) financial cost ratio: (EBT / EBIT), and (b) financial structure ratio (invested capital / equity), whereas,

3. Business taxation by means of Tax effect ratio: (Earnings After Taxes or EAT / EBT); the higher the tax rate will be, the lower will be ROE.

This "really" modified DuPont model employees the aforementioned five ratios to identify the actual and most impactful deriver of ROE and enables the management to improve the ROE by focusing on these ratios.

Considering the multiplicative nature of the DuPont equation, even minute variations in any of the categories can have a significant impact on the returns to equity holders.

Although, the DuPont analysis plays a vital role in enabling the analysts to make informed decisions regarding equity holding. However, the garbage in and garbage out technique of the analysis sometimes makes it harder for the analysts to determine the actual profitability of the company. In other words, DuPont model relies on accounting data from company's annual statements, which can easily be manipulated to reflect better financial position - thereby, making the authenticity of the assessment a bit dubious.

The essence of financial ratio analysis and its applications lie in the comparison of company's numbers with that of its closest business peers or with its own historical performance.

Distinct accounting practices along with seasonal factors also play a crucial role in determining the ROE of the economy and thereby making the analysis a little complicated such as some industries like fashion sector is high margin industry; whereas few such as financial organizations operate in highly leveraged industry. Most importantly, cost of capital is one of the key interest area of the management, which is neglected in DuPont 
framework as a result of investor might get deceived by the ROE of highly leveraged industry while overlooking the risk associated with it (HARGRAVE, 2019).
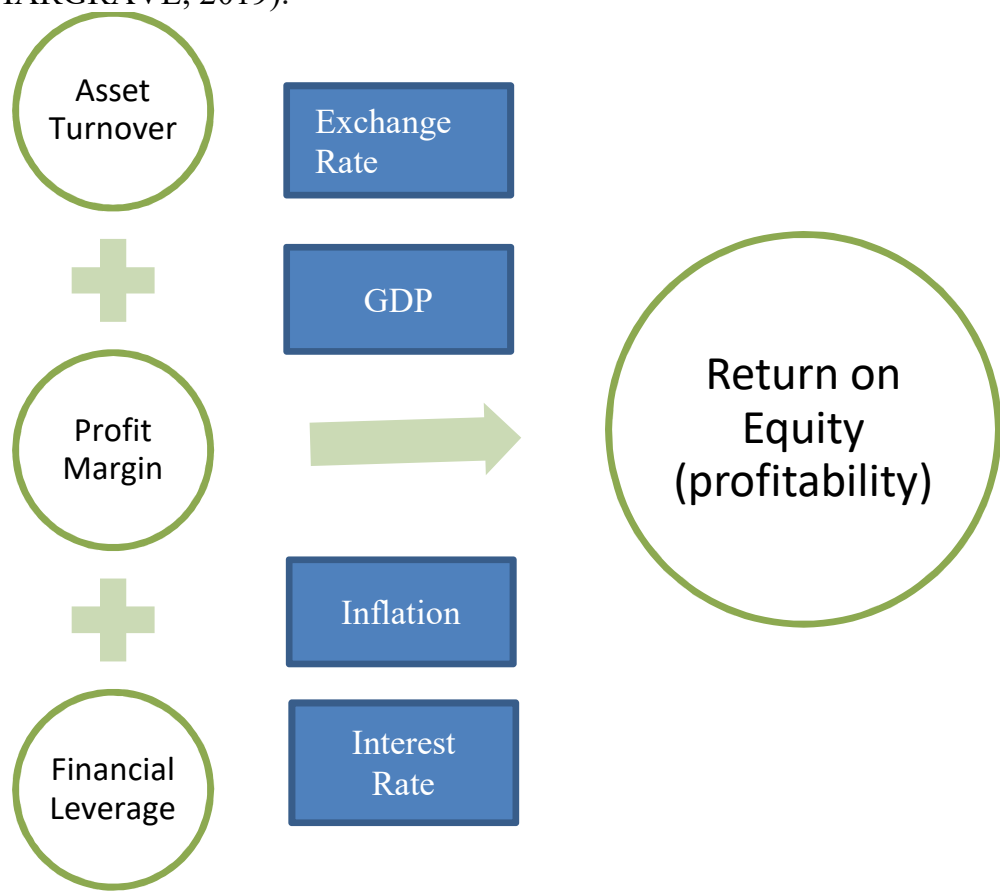

\section{Pakistan's economy at a glance - Du-Pont Approach}

\subsection{Profit Margin}

\begin{tabular}{|l|l|l|l|l|l|}
\hline \multicolumn{1}{|l|}{ Profit Margin } & Cement & Fertilizer & Power & Oil and Gas & Automobile \\
\hline & $2.99 \%$ & $24.18 \%$ & $4.60 \%$ & $2.17 \%$ & $3.77 \%$ \\
\hline 2011 & $14.31 \%$ & $13.62 \%$ & $6.32 \%$ & $1.18 \%$ & $3.45 \%$ \\
\hline 2013 & $20.37 \%$ & $26.01 \%$ & $7.79 \%$ & $-0.45 \%$ & $4.59 \%$ \\
\hline 2014 & $18.85 \%$ & $31.91 \%$ & $7.82 \%$ & $-0.21 \%$ & $5.15 \%$ \\
\hline 2015 & $21.43 \%$ & $22.79 \%$ & $12.05 \%$ & $-0.28 \%$ & $8.05 \%$ \\
\hline 2016 & $22.45 \%$ & $20.04 \%$ & $16.48 \%$ & $0.98 \%$ & $7.74 \%$ \\
\hline 2017 & $21.84 \%$ & $20.51 \%$ & $15.43 \%$ & $1.62 \%$ & $9.12 \%$ \\
\hline
\end{tabular}

The above charts shows the annual averages of profit margin in all the sectors. As you can see in the charts that the contribution of cement sector in terms of Profit margin is highest in 2017 among all the sectors which is $21.84 \%$. It's highest because of the infrastructure growth in Pakistan. 


\subsection{ASSET TURNOVER}

\section{Profit Margin}

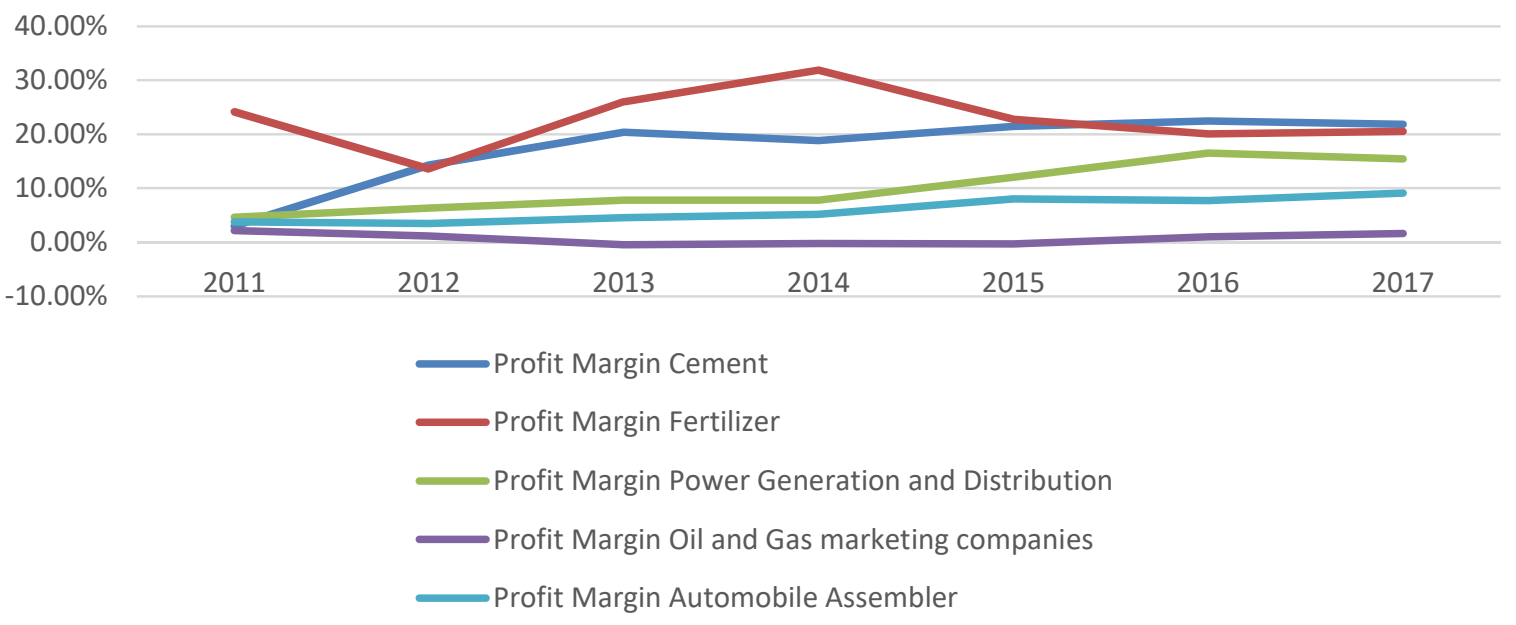

\begin{tabular}{|c|c|c|c|c|c|}
\hline \multicolumn{6}{|c|}{ Asset Turnover } \\
\hline & Cement & Fertilizer & $\begin{array}{l}\text { Power Generation } \\
\text { and Distribution }\end{array}$ & $\begin{array}{l}\text { Oil and Gas } \\
\text { marketing companies }\end{array}$ & $\begin{array}{l}\text { Automobile } \\
\text { Assembler }\end{array}$ \\
\hline 2011 & $61.60 \%$ & $77.20 \%$ & $81.80 \%$ & $311.20 \%$ & $259.60 \%$ \\
\hline 2012 & $71.80 \%$ & $72.40 \%$ & $84.40 \%$ & $313.60 \%$ & $257.00 \%$ \\
\hline 2013 & $74.60 \%$ & $79.20 \%$ & $95.80 \%$ & $333.10 \%$ & $259.20 \%$ \\
\hline 2014 & $78.60 \%$ & $65.60 \%$ & $1436.20 \%$ & $366.60 \%$ & $247.80 \%$ \\
\hline 2015 & $69.80 \%$ & $88.20 \%$ & $86.00 \%$ & $296.80 \%$ & $278.80 \%$ \\
\hline 2016 & $69.20 \%$ & $58.00 \%$ & $61.00 \%$ & $226.80 \%$ & $229.80 \%$ \\
\hline 2017 & $62.60 \%$ & $51.60 \%$ & $67.60 \%$ & $240.00 \%$ & $213.00 \%$ \\
\hline
\end{tabular}

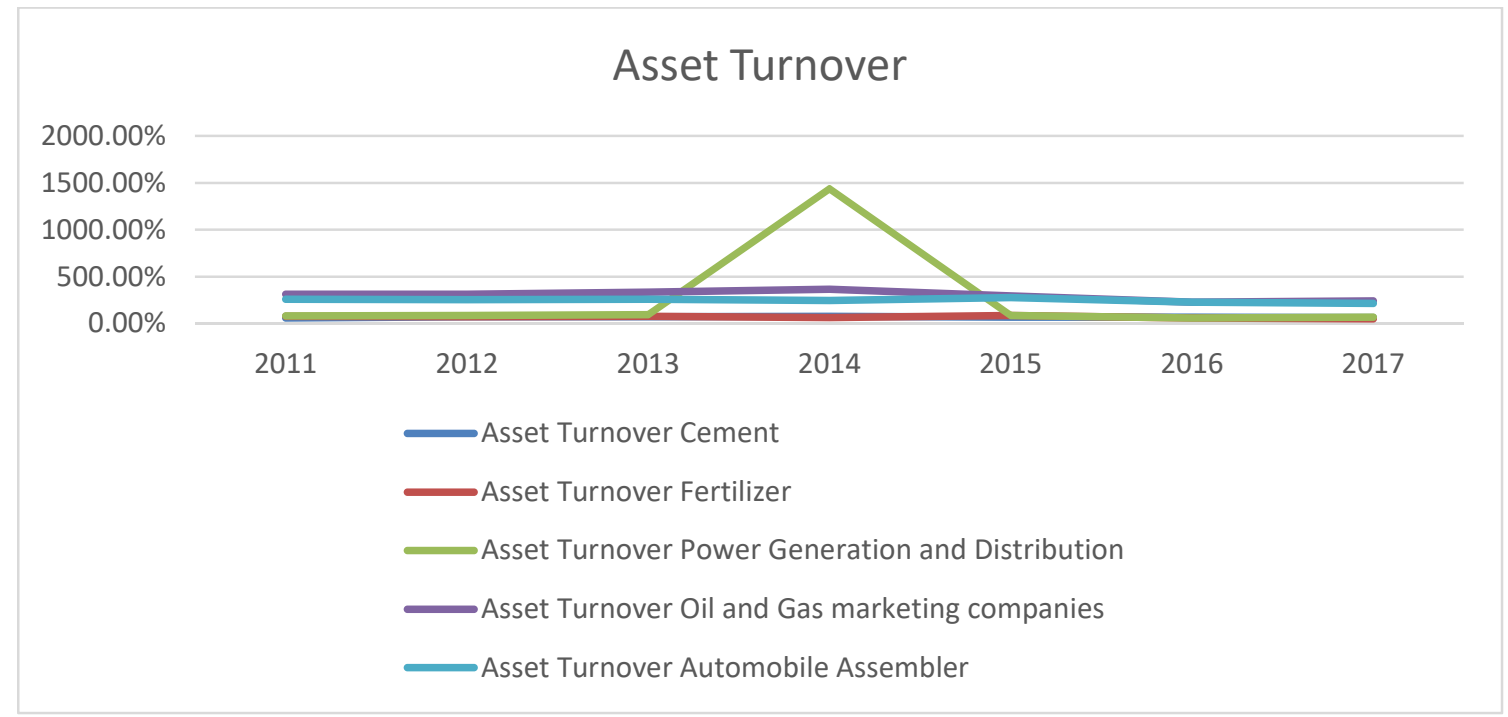

The above charts shows the annual averages of Asset Turnover in all the sectors. As you can see in the charts that the contribution of Oil and Gas sector in terms of Asset Turnover is highest in 2017 among all the sectors which is $240 \%$. It's highest which shows that oil and gas sector is the most efficient sector among all the sectors. 


\subsection{FINANCIAL LEVEAGE}

\begin{tabular}{|l|l|l|l|l|l|}
\hline & Cement & Fertilizer & $\begin{array}{l}\text { Power } \begin{array}{c}\text { Generation } \\
\text { and Distribution }\end{array} \\
\text { Ond }\end{array}$ & $\begin{array}{l}\text { Oil and } \\
\text { marketing } \\
\text { companies }\end{array}$ & $\begin{array}{l}\text { Gas } \\
\text { Automobile } \\
\text { Assembler }\end{array}$ \\
\hline 2011 & $222 \%$ & $317.80 \%$ & $550.20 \%$ & $535.00 \%$ & $271.60 \%$ \\
\hline 2012 & $197 \%$ & $315.00 \%$ & $527.80 \%$ & $619.40 \%$ & $303.60 \%$ \\
\hline 2013 & $178 \%$ & $294.20 \%$ & $339.80 \%$ & $833.10 \%$ & $350.20 \%$ \\
\hline 2014 & $162 \%$ & $266.00 \%$ & $380.38 \%$ & $1028.40 \%$ & $225.60 \%$ \\
\hline 2015 & $169 \%$ & $374.80 \%$ & $310.80 \%$ & $1748.60 \%$ & $193.00 \%$ \\
\hline 2016 & $154 \%$ & $391.20 \%$ & $307.00 \%$ & $1969.60 \%$ & $197.60 \%$ \\
\hline
\end{tabular}

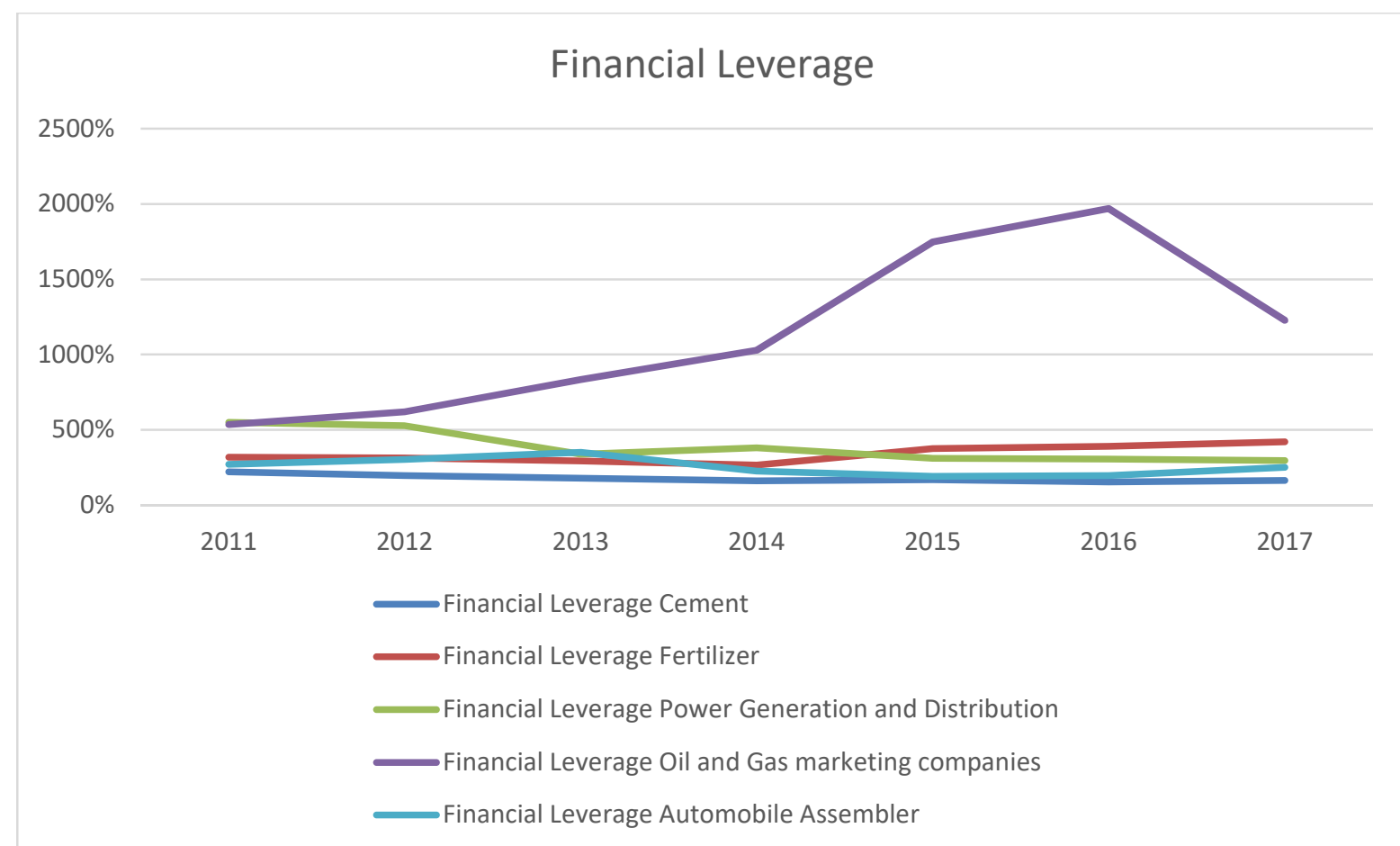

The above charts shows the annual averages of Financial Leverage in all the sectors. As you can see in the charts that the contribution of Oil and Gas sector in terms of Asset Turnover is highest in 2017 among all the sectors which is $1227.00 \%$. It's highest which shows that oil and gas sector is the most leveraged sector among all the sectors.

\subsection{RETURN ON EQUITY}

\begin{tabular}{|l|l|l|l|l|l|}
\hline & Cement & Fertilizer & $\begin{array}{l}\text { Power } \begin{array}{c}\text { Generation } \\
\text { and Distribution }\end{array} \\
\text { Oil and Gas marketing } \\
\text { companies }\end{array}$ & $\begin{array}{l}\text { Automobile } \\
\text { Assembler }\end{array}$ \\
\hline 2011 & $1.94 \%$ & $47.48 \%$ & $16.47 \%$ & $23.23 \%$ & $15.16 \%$ \\
\hline 2012 & $16.39 \%$ & $27.56 \%$ & $26.39 \%$ & $10.19 \%$ & $10.05 \%$ \\
\hline 2013 & $25.25 \%$ & $34.28 \%$ & $23.39 \%$ & $-9.45 \%$ & $23.44 \%$ \\
\hline 2014 & $23.00 \%$ & $32.13 \%$ & $410.10 \%$ & $-7.50 \%$ & $24.39 \%$ \\
\hline 2015 & $23.74 \%$ & $40.64 \%$ & $30.31 \%$ & $-12.99 \%$ & $43.58 \%$ \\
\hline 2016 & $23.12 \%$ & $34.27 \%$ & $29.42 \%$ & $12.52 \%$ & $35.53 \%$ \\
\hline
\end{tabular}




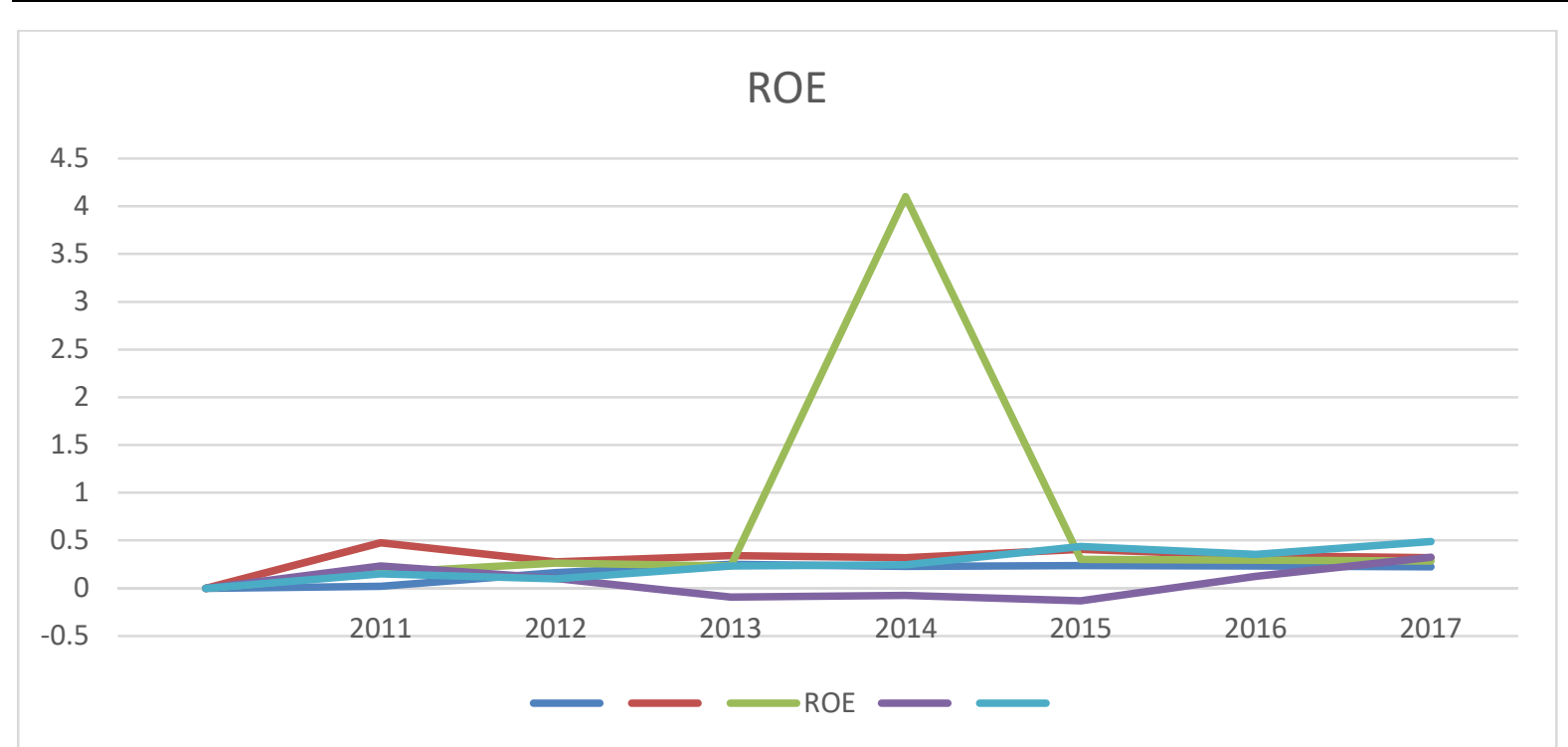

The above charts shows the annual averages of ROE in all the sectors. As you can see in the charts that the contribution of Power sector in terms of Asset Turnover is highest in 2017 among all the sectors which is $48.95 \%$. It's highest which shows that oil and gas sector has the highest among all the sectors.

\subsection{Sectorial Analysis}

\subsubsection{POWER SECTOR}

Power scarcity is the primary economic challenge faced by Pakistan in recent five years, due to this power generation comes under the top priority of the government. Initially the dues of Independent Power Producers (IPPs) public sector power entities ranging Rs 480 billion was entirely pay doff during 2013, because of which the production of electricity was increased by $1700 \mathrm{MWs}$ in the national grid which helps to control load shedding in the country. Furthermore, to make the power sector financially strong and steady, the government started to offer limited subsidies to its consumers (nationally up to 300 units) for the purpose of easy cost retrieval. In the start of 2018, the electricity production get increased from 22812 MW in 2012-13 to 29573 MW in February 2018 which signifies an increase of $30 \%$ growth in the sector.

\subsubsection{OIL AND GAS SECTOR}

The oil and gas sector is the most important contributor of the economy for any country. This sector has a massive contribution in Pakistan's economy. Pakistan is a country which is gifted with many natural resources from which oil and gas are one of them. Pakistan have many reserves of oil and gas and this sector is a major contributor in the GDP and tax chequer of Pakistan. Pakistan has the oil reserves of around ( 0.31 billion barrels), gas (185 billion tons) and shale gas reserves of 51 TCF (Saleh, 2015).

\subsubsection{FERTILIZER SECTOR}

The fertilizer industry of Pakistan has a great potential and It is going to become one of the largest exporter in the region in the coming years. It is possible because of the recent issuance of LNG regasification licences and because of the creation of new fertilizer plants by recognized organizations. Being primarily an agrarian state, Pakistan's growth is heavily dependent on the fertilizer industry. According to reports, Pakistan's fertilizer demand has always remained higher than its supply. In the first half of 2018 alone, cumulative sales of urea increased $45 \%$ to 1.63 million tons and DAP sales edged up $6 \%$ to 434,000 tons. Moreover, with the onset of Kharif sowing season, a further pick-up in demand for urea can be foreseen. Also, comfortable inventory levels of urea and DAP have improved pricing power for local fertilizer manufacturers and as a result, average urea price has increased by $4.70 \%$ month-on-month. At present, international urea and DAP prices were hovering around $\$ 240$ and $\$ 385$ per ton, respectively, and are expected to remain steady which, along with removal of price cap (Rs 1,400 per bag) from urea, would provide an added advantage to local manufacturers.so according to the above stats it creates a very big impact on the GDP as well as on the tax chequers (KHAN, 2018).

\subsubsection{CEMENT SECTOR}

The cement sector of Pakistan is one of the largest contributor in the economy (Ali, 2015). Its contribution is not only effective for the manufacturing sector but it's also important for the economic development of Pakistan (Ahmed, 2016). In the beginning it was a very small industry but with the passage of time it shows rapid growth and finally it entered in the export market. According to the data revealed by all Pakistan manufacturers association (APCMA) during the fiscal year 2017-2018, domestic consumption stood at 41.147 million tons, an increase of $15.42 \%$ from 35.651 million tons in 2016-2017 (BAIG, 2018). However, exports grew by only $1.77 \%$ from 4.664 million tons in 2016-207 to 4.746 million tons during 2017-2018. It comes among the highest contributor to the 
national exchequer with the contribution of approximately 80 billion rupees.

\subsubsection{Auto Sector}

Auto sector is the emerging industry of Pakistan and it plays a significant role in Pakistan's economy. Pakistan is a very good market for automobiles and auto parts and it provides better business and investment opportunities (Atique \& Jamil, 2009). In the past three years it gives a very massive growth and creates employment for 120000 people ("Pakistan's Automobile sector posts growth in 2016-17 fiscal year", 2017). The contribution of this sector is 12 billion rupees to the GDP and 30 billion rupees to the national exchequer in means of taxes and duties (Kazmi, 2017).

\section{METHODOLOGY}

\subsection{Research Design}

The study conducted in this research paper is quantitative in nature and is backed by the following financial figures of ROE(return on equity), Profit margin, Asset turnover, Financial Leverage and macro-economic factors which includes Interest rates, GDP(gross domestic product), Exchange rates, Inflation. These financial figures are of listed companies of 5 different industries of Pakistan Stock Exchange and the data is gathered from their AGRs (Annual General Reports). The names of the industries are Cement sector, Power sector, Oil and Gas sector, Fertilizer sector and Automobile sector.

The profitability of the above five industries will be regressed by taking ROE as a dependent variable while the remaining factors as an independent variables which are Profit margin, Asset turnover, Financial leverage, GDP, Inflation, Exchange rates and Interest rates.

Then the above financial figures are adjusted in the GMM and LS model of "eviews" to identify the most significant driver of profitability among all the factors with reference to the Du-Pont equation.

\subsection{Research Procedure}

In order to addresses the research problem that is "which factor is the driver of profitability among the components of DuPont equation in PSX", regression analysis has been conducted on statistical models for hypothesis testing to identify the impact of independent variables among profit margin, asset turnover, financial leverage and macroeconomic factors (such as interest rates, exchange rates, GDP, inflation) on dependent variable, which is ROE.

To attain the desired research objective, fourteen different models have been formulated on the basis of aforementioned variables. Firstly, LS regression model has been applied on five most vibrant economic sectors of PSX (stated above) and each economic sector has been assessed on seven year financial performance of five listed companies without involving the macro economic factors by using the panel approach.

After assessing the impact of Asset turnover, profit margin and financial leverage on stand -alone basis, that is, without considering the macro-economic factors, least square regression method was capitalized to determine the impact of Du-Pont variables of five different industries along with macro-economic factors on ROE.

Sector-wise analysis of ROE (with and without macro-economic factors) is followed by comprehensive same panel LS and GMM analysis that will refine the research findings by addressing the issues of weighting matrix estimation and coefficient covariance calculation.

Moreover, in order to assure the accuracy of financial information and its viability, data from Annual General Reports of 25 companies listed in Pakistan Stock Exchange have been extracted (details stated below):

\begin{tabular}{|c|c|c|c|c|}
\hline Automobile & Cement & Fertilizer & Oil and Gas & Power \\
\hline $\begin{array}{l}\text { Indus Motor Co } \\
\text { Ltd }\end{array}$ & $\begin{array}{l}\text { Lucky Cement } \\
\text { Limited }\end{array}$ & $\begin{array}{ll}\text { Engro } & \text { Fertilizers } \\
\text { Limited } & \end{array}$ & Shell Pakistan Ltd & $\begin{array}{ll}\text { Nishat } & \text { Chunian } \\
\text { Power Ltd } & \end{array}$ \\
\hline Millat Tractors Ltd & $\begin{array}{l}\text { Attock Cement } \\
\text { Limited }\end{array}$ & $\begin{array}{l}\text { Dawood Hercules } \\
\text { Limited }\end{array}$ & $\begin{array}{l}\text { Pakistan State Oil } \\
\text { Co Ltd }\end{array}$ & $\begin{array}{l}\text { Kot Addu Power Co } \\
\text { Ltd KAPCO }\end{array}$ \\
\hline $\begin{array}{l}\text { Pak Suzuki Motors } \\
\text { Co Ltd }\end{array}$ & $\begin{array}{l}\text { Maple Leaf } \\
\text { Cement Limited }\end{array}$ & $\begin{array}{l}\text { Fauji Fertilizer Bin } \\
\text { Qasim Limited }\end{array}$ & $\begin{array}{l}\text { Sui Northern Gas } \\
\text { Pipelines Ltd }\end{array}$ & $\begin{array}{l}\text { Hub Power Co Ltd } \\
\text { HUBC }\end{array}$ \\
\hline Atlas Honda Ltd & $\begin{array}{l}\text { D.G. Khan } \\
\text { Cement Limited }\end{array}$ & $\begin{array}{l}\text { Fatima } \\
\text { Limited }\end{array}$ & $\begin{array}{l}\text { Sui Southern Gas } \\
\text { Co Ltd }\end{array}$ & K-Electric Ltd \\
\hline $\begin{array}{l}\text { Honda Atlas Cars } \\
\text { Pakistan Ltd }\end{array}$ & $\begin{array}{l}\text { Bestway Cement } \\
\text { Limited }\end{array}$ & Fauji Fertilizer Ltd. & $\begin{array}{l}\text { Attock Petroleum } \\
\text { Ltd }\end{array}$ & Nishat Power Ltd \\
\hline
\end{tabular}


Method: Panel Least Squares

\begin{tabular}{|c|c|c|c|c|c|c|c|c|c|c|c|c|}
\hline & $\begin{array}{l}\text { Model 1 } \\
\text { Auto }\end{array}$ & $\begin{array}{l}\text { Model } 2 \\
\text { Cement }\end{array}$ & $\begin{array}{l}\text { Model } 3 \\
\text { Fertilizer } \\
\end{array}$ & $\begin{array}{l}\text { Model } 4 \\
\text { Oil and Gas }\end{array}$ & $\begin{array}{l}\text { Model } 5 \\
\text { Power }\end{array}$ & $\begin{array}{l}\text { Model } 6 \\
\text { Auto }\end{array}$ & $\begin{array}{l}\text { Model } 7 \\
\text { Cement }\end{array}$ & $\begin{array}{l}\text { Model } 8 \\
\text { Fertilizer }\end{array}$ & $\begin{array}{l}\text { Model } 9 \\
\text { Oil and Gas }\end{array}$ & $\begin{array}{l}\text { Model } 10 \\
\text { Power }\end{array}$ & $\begin{array}{l}\text { Model } 11 \\
\text { All Sectors }\end{array}$ & $\begin{array}{l}\text { Model } 12 \\
\text { All Sectors }\end{array}$ \\
\hline CONSTANT & $\begin{array}{l}-0.5366 \\
(0.0000)\end{array}$ & $\begin{array}{l}-0.3451 \\
(0.0000)\end{array}$ & $\begin{array}{l}-0.2995 \\
(0.0394)\end{array}$ & $\begin{array}{l}0.0038 \\
(0.9673)\end{array}$ & $\begin{array}{l}-0.3698 \\
(0.0027)\end{array}$ & $\begin{array}{l}1.2879 \\
(0.5703)\end{array}$ & $\begin{array}{l}-0.0665 \\
(0.9506)\end{array}$ & $\begin{array}{l}-0.1741 \\
(0.9667)\end{array}$ & $\begin{array}{l}-0.1298 \\
(0.9805)\end{array}$ & $\begin{array}{l}0.1046 \\
(0.9619)\end{array}$ & $\begin{array}{l}-0.3859 \\
(0.0000)\end{array}$ & $\begin{array}{l}-0.2450 \\
(0.9523)\end{array}$ \\
\hline ASSET & 0.1480 & $\begin{array}{l}0.2696 \\
0\end{array}$ & 0.5689 & $\begin{array}{l}-0.0005 \\
0.8377\end{array}$ & 0.2867 & $\begin{array}{l}0.1614 \\
0\end{array}$ & 0.2683 & 0.6329 & $\begin{array}{l}0.0090 \\
0.7261\end{array}$ & $\begin{array}{l}0.2864 \\
0\end{array}$ & 0.2765 & $\begin{array}{l}0.2777 \\
0\end{array}$ \\
\hline FINANCIAL & 0.0286 & 0.0697 & 0.0225 & -0.0024 & 0.0365 & 0.0290 & 0.0702 & 0.0136 & -0.0031 & 0.0671 & -0.0025 & -0.0031 \\
\hline LEVERAGE & $(0.0031)$ & $(0.0001)$ & $(0.328)$ & $(0.4207)$ & $(0.0473)$ & $(0.0035)$ & $(0.0007)$ & $(0.5634)$ & $(0.3171)$ & $(0.0063)$ & $(0.5285)$ & $(0.4371)$ \\
\hline PROFIT & 6.3820 & 1.3004 & 0.7814 & 13.0913 & 2.4951 & 6.0693 & 1.3189 & 0.8428 & 12.1098 & 3.8789 & 1.8293 & 1.8073 \\
\hline MARGIN & $(0.0000)$ & $(0.0000)$ & $(0.0006)$ & $(0.0000)$ & $(0.0000)$ & $(0.0000)$ & $(0.0000)$ & $(0.0003)$ & $(0.0000)$ & $(0.0000)$ & $(0.0000)$ & $(0.0000)$ \\
\hline $\begin{array}{l}\text { EXCHANGE } \\
\text { RATES }\end{array}$ & & & & & & $\begin{array}{l}-0.0097 \\
(0.3953)\end{array}$ & $\begin{array}{l}0.0002 \\
(0.9703)\end{array}$ & $\begin{array}{l}-0.0351 \\
(0.0979)\end{array}$ & $\begin{array}{l}-0.0201 \\
(0.4778)\end{array}$ & $\begin{array}{l}\mathbf{0 . 0 2 0 3} \\
(0.1075)\end{array}$ & & $\begin{array}{l}-0.0329 \\
(0.098)\end{array}$ \\
\hline GDP & & & & & & -0.0212 & -0.0275 & 0.4388 & 0.3086 & -0.3382 & & 0.4145 \\
\hline ANNUAL & & & & & & $(0.8845)$ & $(0.683)$ & $(0.1201)$ & $(0.4076)$ & $(0.0643)$ & & $(0.1169)$ \\
\hline INFLATION & & & & & & 0.0164 & 0.0050 & -0.0251 & -0.0011 & 0.0311 & & -0.0303 \\
\hline ANNUAL & & & & & & $(0.4291)$ & $(0.5963)$ & $(0.5106)$ & $(0.9821)$ & $(0.1907)$ & & $(0.4185)$ \\
\hline INTEREST & & & & & & -0.1905 & -0.0457 & 0.3285 & 0.1595 & -0.3081 & & 0.3162 \\
\hline RATES & & & & & & $(0.4438)$ & $(0.6927)$ & $(0.4783)$ & $(0.79)$ & $(0.2517)$ & & $(0.4855)$ \\
\hline R-squared & 0.86372 & 0.88637 & 0.58695 & 0.73561 & 0.99930 & 0.88039 & 0.88787 & 0.65784 & 0.76084 & 0.99943 & 0.93434 & 0.93664 \\
\hline Adj R sq & 0.85053 & 0.87537 & 0.54698 & 0.71003 & 0.99924 & 0.84937 & 0.85880 & 0.56913 & 0.69884 & 0.99929 & 0.93319 & 0.93398 \\
\hline F-statistic & 65.489 & 80.605 & 14.684 & 28.751 & 14805.0 & 28.389 & 30.543 & 7.416 & 12.271 & 6785.96 & 811.157 & 352.667 \\
\hline Prob(F-stat) & $(0.0000)$ & $(0.0000)$ & $(0.0000)$ & $(0.0000)$ & $(0.0000)$ & $(0.0000)$ & $(0.0000)$ & $(0.0000)$ & $(0.0000)$ & $(0.0000)$ & $(0.0000)$ & $(0.0000)$ \\
\hline DW stat. & 1.0776 & 0.7952 & 0.9230 & 0.9735 & 0.7128 & 1.1804 & 0.7869 & 0.9621 & 1.0524 & 0.7391 & 0.4521 & 0.4348 \\
\hline
\end{tabular}

P-Values in Parenthesis

Dependent Variable: ROE

Sample: 20112017

Method: Panel Generalized Method of Moments (First Differences)

\begin{tabular}{l|ll} 
& $\begin{array}{l}\text { Model 13 } \\
\text { All Sectors }\end{array}$ & $\begin{array}{l}\text { All Sectors } \\
\text { ROE(-1) }\end{array}$ \\
\hline 0.009969 & $\mathbf{- 0 . 0 0 0 1 2}$ \\
ASSET & $\mathbf{0 . 2 8 8 1 1}$ & $\mathbf{0 . 4 5 3 7 4 1}$ \\
TURNOVER & $(0.0000)$ & $(0.2742)$ \\
EXCHANGE & $\mathbf{- 0 . 0 2 3 3 3}$ & \\
RATES & $(0.0000)$ & \\
FINANCIA & $\mathbf{- 0 . 0 1 0 8 3}$ & $\mathbf{- 0 . 0 1 3 0 7}$ \\
LLEVERAGE & $(0.0000)$ & $(0.0000)$ \\
GDP & $\mathbf{0 . 4 2 0 9 9 8}$ & \\
ANNUAL & $(0.0000)$ & \\
INFLATION & $\mathbf{- 0 . 0 4 1 9 3}$ & \\
ANNUAL & $(0.0000)$ & \\
INTEREST & $\mathbf{0 . 4 0 1 5 5 1}$ & \\
RATES & $(0.0000)$ & \\
PROFIT & $\mathbf{0 . 5 9 2 0 6 6}$ & $\mathbf{0 . 3 0 0 2 1 8}$ \\
MARGIN & $(0.0000)$ & $(0.0000)$ \\
\hline J-statistic & 19.13308 & 9.624562 \\
Effect: &
\end{tabular}

Effect: Cross-section fixed

Instrument specification: ROE, ROE (-2 Lags), ASSET TURNOVER, EXCHANGE RATES, FINANCIALEVERAGE, GDP, INFLATION, INTEREST RATES, PROFIT MARGIN

Dependent Variable: ROE

Sample: 20132017

\subsection{Results}

In model 1 we consider only the du-Pont identity variables not the macro-economic factors of the auto industry. This model shows that profit margin is the variable which contributes the most among the three variable (profit margin, financial leverage and asset turnover) of du-Pont identity. The contribution of profit margin is 6.3820 which is the highest among all the variables, after this asset turn over contributes 0.1480 and the least contribution is of financial leverage which is 0.0286 . This result shows that profit margin is the driver of profitability among the du-Pont identity which affect the most to ROE. The probability of the model is zero, the R-square value of the model is $86.3 \%$ and the adjusted $\mathrm{R}$-square value is $85.05 \%$ which shows that the model is significant because the 
probability of the model is below $5 \%$ and the value of the R-square is above $75 \%$.

In model 2 we consider only the du-Pont identity variables not the macro-economic factors of the cement industry. This model also shows that profit margin is the variable which contributes the most among the three variable (profit margin, financial leverage and asset turnover) of du-Pont identity. The contribution of profit margin is 1.3004 which is the highest among all the variables, after this asset turn over contributes 0.2696 and the least contribution is of financial leverage which is 0.0697 . This result shows that profit margin is the driver of profitability among the du-Pont identity which affect the most to ROE. The probability of the model is zero, the $\mathrm{R}$-square value of the model is $88.537 \%$ and the adjusted $\mathrm{R}$-square value is $87.537 \%$ which shows that the model is significant because the probability of the model is below $5 \%$ and the value of the R-square is above $75 \%$.

In model 3 we consider only the du-Pont identity variables not the macro-economic factors of the fertilizer industry. This model also shows that profit margin is the variable which contributes the most among the three variable (profit margin, financial leverage and asset turnover) of du-Pont identity. The contribution of profit margin is 0.7814 which is the highest among all the variables, after this asset turn over contributes 0.5689 and the least contribution is of financial leverage which is 0.0225 . This result shows that profit margin is the driver of profitability among the du-Pont identity which affect the most to ROE. The probability of the model is zero, the R-square value of the model is $58.695 \%$ and the adjusted R-square value is $54.698 \%$ which shows that the model is significant because the probability of the model is below $5 \%$ and the value of the R-square is above $75 \%$.

In model 4 we consider only the du-Pont identity variables not the macro-economic factors of the oil and gas industry. This model also shows that profit margin is the variable which contributes the most among the three variable (profit margin, financial leverage and asset turnover) of du-Pont identity. The contribution of profit margin is 13.0913 which is the highest among all the variables, after this asset turn over contributes -0.0005 and the least contribution is of financial leverage which is -0.0024 . This result shows that profit margin is the driver of profitability among the du-Pont identity which affect the most to ROE. The probability of the model is zero, the $\mathrm{R}$-square value of the model is $73.561 \%$ and the adjusted $\mathrm{R}$-square value is $71.003 \%$ which shows that the model is significant because the probability of the model is below $5 \%$ and the value of the R-square is above $75 \%$.

In model 5 we consider only the du-Pont identity variables not the macro-economic factors of the power industry. This model also shows that profit margin is the variable which contributes the most among the three variable (profit margin, financial leverage and asset turnover) of du-Pont identity. The contribution of profit margin is 2.4951 which is the highest among all the variables, after this asset turn over contributes 0.2867 and the least contribution is of financial leverage which is 0.0365 . This result shows that profit margin is the driver of profitability among the du-Pont identity which affect the most to ROE. The probability of the model is zero, the $\mathrm{R}$-square value of the model is $99.93 \%$ and the adjusted R-square value is $99.924 \%$ which shows that the model is significant because the probability of the model is below $5 \%$ and the value of the R-square is above $75 \%$.

In model 6 we consider both the du-pont identity variables as well as the macro-economic factors for the analysis of auto sector. After taking results from the model made up of both du-pont variables and the macroeconomic factors there is no change in the driver of profitability. In this model the driver of profitability remains the same which profit margin. The contribution of profit margin is 6.0693 which is the highest among all (du-pont variable and macro-economic variables), after this asset turn over contributes 0.1614 and least contribution is of financial leverage which is 0.0290 whereas the impact of macro-economic factors is that, exchange rates effects ROE by -0.0097 ,GDP effects ROE by -0.0212 , inflation rates effects ROE by 0.0164 and in the last interest rates effects ROE by 0.1905 . This result shows that profit margin is the driver of profitability among the du-Pont identity which affect the most to ROE. The probability of the model is zero, the R-square value of the model is $88.039 \%$ and the adjusted R-square value is $84.937 \%$ which shows that the model is significant because the probability of the model is below $5 \%$ and the value of the R-square is above $75 \%$.

In model 7 we consider both the du-pont identity variables as well as the macro-economic factors for the analysis of cement sector. After taking results from the model made up of both du-pont variables and the macroeconomic factors there is no change in the driver of profitability. In this model the driver of profitability remains the same which profit margin. The contribution of profit margin is 1.3189 which is the highest among all (du-pont variable and macro-economic variables), after this asset turn over contributes 0.2683 and least contribution is of financial leverage which is 0.0702 whereas the impact of macro-economic factors is that, exchange rates effects ROE by 0.0002 , GDP effects ROE by -0.0275 , inflation rates effects ROE by 0.0050 and in the last interest rates effects ROE by -0.0457 . This result shows that profit margin is the driver of profitability among the du-Pont identity which affect the most to ROE. The probability of the model is zero, the R-square value of the model is $88.787 \%$ and the adjusted R-square value is $85.880 \%$ which shows that the model is significant because the probability of the model is below $5 \%$ and the value of the R-square is above $75 \%$.

In model 8 we consider both the du-pont identity variables as well as the macro-economic factors for the analysis of Fertilizer sector. After taking results from the model made up of both du-pont variables and the macroeconomic factors there is no change in the driver of profitability. In this model the driver of profitability remains the same which profit margin. The contribution of profit margin is 0.8428 which is the highest among all (du-pont 
variable and macro-economic variables), after this asset turn over contributes 0.6329 and least contribution is of financial leverage which is 0.0136 whereas the impact of macro-economic factors is that, exchange rates effects ROE by -0.0351, GDP effects ROE by 0.4388 , inflation rates effects ROE by -0.0251 and in the last interest rates effects ROE by 0.3285 . This result shows that profit margin is the driver of profitability among the du-Pont identity which affect the most to ROE. The probability of the model is zero, the R-square value of the model is $65.784 \%$ and the adjusted R-square value is $56.913 \%$ which shows that the model is significant because the probability of the model is below $5 \%$ and the value of the R-square is above $75 \%$.

In model 9 we consider both the du-pont identity variables as well as the macro-economic factors for the analysis of Oil and Gas sector. After taking results from the model made up of both du-pont variables and the macro-economic factors there is no change in the driver of profitability. In this model the driver of profitability remains the same which profit margin. The contribution of profit margin is 12.1098 which is the highest among all (du-pont variable and macro-economic variables), after this asset turn over contributes 0.0090 and least contribution is of financial leverage which is -0.0031 whereas the impact of macro-economic factors is that, exchange rates effects ROE by -0.0201 ,GDP effects ROE by 0.3086 , inflation rates effects ROE by -0.0011 and in the last interest rates effects ROE by 0.1595 . This result shows that profit margin is the driver of profitability among the du-Pont identity which affect the most to ROE. The probability of the model is zero, the R-square value of the model is $76.084 \%$ and the adjusted R-square value is $69.884 \%$ which shows that the model is significant because the probability of the model is below $5 \%$ and the value of the R-square is above $75 \%$.

In model 10 we consider both the du-pont identity variables as well as the macro-economic factors for the analysis of Power sector. After taking results from the model made up of both du-pont variables and the macroeconomic factors there is no change in the driver of profitability. In this model the driver of profitability remains the same which profit margin. The contribution of profit margin is 3.8789 which is the highest among all (du-pont variable and macro-economic variables), after this asset turn over contributes 0.2864 and least contribution is of financial leverage which is 0.0671 whereas the impact of macro-economic factors is that, exchange rates effects ROE by 0.0203 ,GDP effects ROE by -0.3382 , inflation rates effects ROE by 0.0311 and in the last interest rates effects ROE by -0.3081 . This result shows that profit margin is the driver of profitability among the du-Pont identity which affect the most to ROE. The probability of the model is zero, the R-square value of the model is $99.943 \%$ and the adjusted R-square value is $99.929 \%$ which shows that the model is significant because the probability of the model is below $5 \%$ and the value of the R-square is above $75 \%$.

In model 11 we consider the du-Pont identity variables only not the macro-economic factors and run the data of all sectors (auto sector, cement sector, fertilizer sector, oil and gas sector and power sector) in one panel with the help of LS Regression. After taking results from the model made up of du-pont variables, profit margin is the driver of profitability among all the factors of du-pont identity. The contribution of profit margin is 1.8293 which is the highest among all (du-pont variable), after this asset turn over contributes 0.2765 and least contribution is of financial leverage which is -0.0025 . This result shows that profit margin is the driver of profitability among the du-Pont identity which affect the most to ROE. The probability of the model is zero, the R-square value of the model is $93.434 \%$ and the adjusted R-square value is $93.319 \%$ which shows that the model is significant because the probability of the model is below $5 \%$ and the value of the R-square is above $75 \%$.

In model 12 we consider both the du-pont identity variables as well as the macro-economic factors (exchange rates, GDP, inflation rates and Interest rates) for the analysis of all the sectors (auto sector, cement sector, fertilizer sector, oil and gas sector and power sector) in one panel with help of LS regression. After taking results from the model made up of both du-pont variables and the macro-economic factors there is no change in the driver of profitability. In this model the driver of profitability remains the same which is profit margin. The contribution of profit margin is 1.8073 which is the highest among all (du-pont variable and macro-economic variables), after this asset turn over contributes 0.2777 and least contribution is of financial leverage which is -0.0031 whereas the impact of macro-economic factors is that, exchange rates effects ROE by -0.0329 , GDP effects ROE by -0.4145 , inflation rates effects ROE by -0.0303 and in the last interest rates effects ROE by 0.3162 . This result shows that profit margin is the driver of profitability among the du-Pont identity which affect the most to ROE. The probability of the model is zero, the R-square value of the model is $93.664 \%$ and the adjusted R-square value is $93.398 \%$ which shows that the model is significant because the probability of the model is below $5 \%$ and the value of the R-square is above $75 \%$.

In model 13 we consider both the du-pont identity variables as well as the macro-economic factors (exchange rates, GDP, inflation rates and Interest rates) for the analysis of all the sectors (auto sector, cement sector, fertilizer sector, oil and gas sector and power sector) in one panel with help of GMM (Generalized Method For Moments) regression. After taking results from the model made up of both du-pont variables and the macro-economic factors there is no change in the driver of profitability by using GMM regression as well. In this model the driver of profitability remains the same which is profit margin. The contribution of profit margin is 0.592066 which is the highest among all (du-pont variable and macro-economic variables), after this asset turn over contributes 0.28811 and least contribution is of financial leverage which is -0.01083 whereas the impact of macro-economic factors is 
that, exchange rates effects ROE by -0.02333 , GDP effects ROE by 0.420998 , inflation rates effects ROE by 0.04193 and in the last interest rates effects ROE by 0.401551 . This result shows that profit margin is the driver of profitability among the du-Pont identity which affect the most to ROE. The probability of the model is zero, which shows that the model is significant because the probability of the model is below $5 \%$.

In model 14 we consider the du-Pont identity variables only not the macro-economic factors and run the data of all sectors (auto sector, cement sector, fertilizer sector, oil and gas sector and power sector) in one panel with the help of GMM (Generalized Method For Moments) Regression. After taking results from the model made up of du-pont variables, profit margin is the driver of profitability among all the factors of du-pont identity. The contribution of profit margin is 0.453741 which is the highest among all (du-pont variable), after this asset turn over contributes 0.300218 and least contribution is of financial leverage which is -0.01307 . This result shows that profit margin is the driver of profitability among the du-Pont identity which affect the most to ROE. The probability of the model is zero which shows that the model is significant because the probability of the model is below $5 \%$.

\subsection{Discussions}

The results largely validated previous theoretical and empirical studies. For instant, Soliman in (2004) rectified that only the industry-specific Du-Pont components becomes good drivers of Profitability as compared to the macro-economic factors, thats the reason why the validity of industry-specific ratios have increased. Likewise, Majed et al (2012) identified that there is a strong and positive relationship between the share price and the company's performance in terms of ROA, ROE and ROI. Though the part of macro-economic factors was not accounted in this research. The results of this research shows that ROI and ROA has positive but relatively low relationship with market share price but they failed to determine any relationship between ROE and market share price. Saleem Q and Naseem MA (2012) Theorized that reverse relationship exists among influence and productivity in oil and gas area. Be that as it may, their discoveries were not sufficiently definitive to portray a positive connection between Financial Leverage and Profitability. Furthermore, they endeavoured to address their question with respect to the hazard of interest in exceedingly utilized organization as far as profit for value and ran over the way that exceptionally utilized firms were less unsafe in both market-based and bookkeeping based measures. Mubin, Iqbal \& Hussain (2014) have recognized the most predictable or unpredictable DuPont part among profit margin, total asset turnover and equity multiplier in Fuel and Energy Sector, Chemicals Sector, Cement Sector, Engineering Sector, Textiles Sector and Transport and Communication Sector of KSE 100 index. Their exploration found that asset turnover is the most persuasive segment of DuPont structure that decides the productivity of organizations working in Pakistan. In any case, the investigation was directed on remain solitary premise, without contemplating the large scale monetary elements - making the aftereffects of this exploration somewhat questionable. Saleem Q and Naseem MA (2012) proved an inverse relationship between profit margin and the financial leverage. Same is the case in this research paper that in all the models there is an inverse relationship between profit margin and financial leverage in all the sectors. As Mubin, Iqbal \& Hussain (2014) researches In KSX through Du-Pont equation and finalized the result that asset turnover is the driver of profitability but in this research the driver of profitability is profit margin.

\section{Conclusion}

In this research our hypothesis is to determine the driver of profitability in PSX (Pakistan Stock Exchange) through du-Pont identity. To test the hypothesis we have taken 5 different sectors (Auto sector, Cement sector, Fertilizer sector, Oil and Gas sector and Power sector) and 5 different companies from each sectors to signify our research. To analyze this hypothesis we have chosen two different regression techniques one is Least Square (LS) Regression and the second is Generalized Method for Moments (GMM). Initially in the starting 5 models of this research is based on individual sector wise analysis through LS regression without macro-economic factors. In all the above starting five models profit margin is the driver of profitability among the du-pont identity.so, after analyzing the sectors individually (firm wise) then we have taken our results by combining both the du-pont identity and the macro-economic factors to see that how the macro environment effects the companies and how it contradict from the results of the initial five models but the results remains the same. As in the starting five models the driver of profitability is Profit margin, which remains the same in the next five models which are analyzed with both macro-economic factors as well as the du-pont variables. After analyzing sectors individually with and without macro-economic factors till model 10, then we have further analyzed the sectors by running all the sectors in one panel with and without macro-economic factors to determine the driver of profitability. When we run all the sectors in one panel by LS regression in model 11 and 12 the result remains the same that profit margin is the driver of profitability in all the sectors taken from Pakistan's economy. To make this research reliable we have further analyzed the sectors by GMM regression. In model 13 and 14 we have run all the sectors in one panel with and without macro-economic factors, the result remains the same as it was in the LS regression that Profit margin the driver of profitability among the du-pont identity.

By using Least Square Regression and Generalized Methods for Moments (GMM) methodology, we are able 
to identify the driver of profitability among the three key indicators of Du-Pont equation which are Profit Margin, Assets Turnover and financial leverage. Among the three factors profit margin is the most significant factor among the three factors, in both the cases with and without using the macro-economic factors as shown above in the tables. In all the sectors only Profit Margin plays the significant role. As shown in the above tables that in all the models the Probability (F-statistic) is below 5\% which shows the significance of the models and almost in all the sectors the $\mathrm{R} 2$ is above $75 \%$ which also indicates that models are best fitted.

\subsection{FUTURE STUDY}

In the end of this research it is concluded that the driver of profitability among the three key factors (Asset Turnover, Profit Margin and Financial Leverage) of Du-Pont identity is Profit Margin, which has a significant impact on ROE so

- In this research only seven years data is used to determine the most effective factor of Du-Pont identity on ROE (Return on Equity) in Pakistan stock exchange for future researches more number of years data can be used to conduct research.

- In this research only five sectors are used to find out the driver of profitability in Pakistan Stock Exchange (PSX) for further research more sectors can be used.

- Furthermore this research concluded that Profit Margin is the driver of profitability which has the significant impact on ROE in the five sectors but this research do not indicates the noticeable impact in a particular sector which can be further studied.

\section{References}

Ahmed, S. (2016). Cement industry among highest contributors to national exchequer. Retrieved from https://pakobserver.net/cement-industry-among-highest-contributors-to-national-exchequer/

Ali, N. (2015). The role of cement industry in the economic development of Pakistan. EduPedia Publications (P) Ltd.

Atique, M., \& Jamil, B. (2009). Role of Auto Sector in the Growth of Pak GDP. Retrieved from https://www.scribd.com/doc/25106629/Role-of-Auto-Sector-in-the-Growth-of-Pak-GDP

BAIG, Z. (2018). Cement industry posts annual growth of 13.84 percent. Retrieved from https://fp.brecorder.com/2018/07/20180705388237/

Bernstein, L. and J. Wild. 1998. Financial Statement Analysis. 6th ed. Irwin-McGraw Hill.

Brigham, Eugene F., and Houston, Joel F. (2001), Fundamentals of Financial Management, Concise Third Edition, Harcourt Publishers.

Kazmi, S. (2017). Contribution of auto industry to Pakistan economy. Retrieved from http://www.pakistaneconomist.com/2017/09/18/contribution-auto-industry-pakistan-economy/

KHAN, Z. (2018). Fertilizer industry of Pakistan. Retrieved from https://fp.brecorder.com/2018/07/20180708388748/

Lambert, R., Larcker, D., 1987. An analysis of the use of accounting and market measures of performance in executive compensation contracts. Journal of Accounting Research . 85-125.

Leisz TJ and Maranville SJ (2008), 'Ratio Analysis featuring the DuPont method: An overlooked topic in the Finance Module of Small Business Management and Entrepreneurship Courses', Small Business Institute Journal, Vol. 1, pp. $17-34$

Nissim, D. and S.H. Penman. 2001. Ratio analysis and equity valuation: From research to practice. Review of Accounting Studies, 6, 109-154

Pakistan's Automobile sector posts growth in 2016-17 fiscal year. (2017). Retrieved from https://pabausa.org/1336/pakistans-automobile-sector-posts-growth-in-2016-17-fiscal-year/

Palepu, K. \& P. Healy (2008). Business analysis and valuation: Using financial statements (Fourth edition). Mason, $\mathrm{OH}$ : Thomson Southwestern.

Pratt, J. \& D. Hirst. (2008). Financial Reporting for Managers: A Value-Creation Perspective. New York, NY, Wiley

Revsine, L., D. Collins and W. B. Johnson. 1999. Financial Reporting \& Analysis. Upper Saddle River, N.J.: Prentice-Hall, Inc.

Saleem, Q and Rehman, R (2012), 'Impact of Liquidity Ratio on Profitability (Case of Oil and Gas Companies of Pakistan)', Interdisciplinary Journal of Research in Business, Vol. 1, Issue. 7, pp.95 - 98.

Saleh, A. (2015). Oil \& Gas Sector of Pakistan and Sustainable Development. doi: 10.13140/RG.2.1.2415.7288

Saunders, A., (2000) Management of Financial Institutions, Third Edition, McGraw Hill.

Soliman, M. 2004. Using industry-adjusted DuPont analysis to predict future profitability and returns. Ph.D. dissertation, University of Michigan

Soliman, M.T (2008), "The Use of DuPont Analysis by Market Participants", The Accounting Review, Vol. 83 Vol. 3, pp.823-853. 
Stickney, C. and P.Brown. 1999. Financial Reporting and Statement Analysis. 4th ed. New York: Harcourt, Brace \& Co.

Doorasamy, M. (2016). Using DuPont analysis to assess the financial performance of the top 3 JSE listed companies in the food industry. Investment Management And Financial Innovations, 13(2), 29-44. doi: 10.21511/imfi.13(2).2016.04

HORTON, M. (2019). The Difference Between Profitability and Profit. Retrieved from https:/www.investopedia.com/ask/answers/012715/what-difference-between-profitability-and-profit.asp

Hofstrand, D. (2009). Understanding $\quad$ Profitability. $\quad$ Retrieved from https://www.extension.iastate.edu/agdm/wholefarm/html/c3-24.html

Turner, J., Broom, K., Elliott, M., \& Lee, J. (2015). A Decomposition of Hospital Profitability: An Application of DuPont Analysis to the US Market. doi: 10.1177/2333392815590397

Profitability Analysis. Retrieved from http://shodhganga.inflibnet.ac.in/bitstream/10603/705/16/17_chapter8.pdf

Liesz, T. REALLY MODIFIED DU PONT ANALYSIS: FIVE WAYS TO IMPROVE RETURN ON EQUITY. Retrieved from http://citeseerx.ist.psu.edu/viewdoc/download?doi=10.1.1.610.5026\&rep=rep1\&type=pdf

Brigham, Eugene F. and Houston, Joel F. Fundamentals of Financial Management, Concise Third Edition, Harcourt Publishers, 2001.

Hawawini, G. and Viallet. Finance for Executives, South-Western College Publishing, 1999.

Mubin, M., Iqbal, A., \& Hussain, A. (2014). Determinant of Return on Assets and Return on Equity and Its Industry Wise Effects: Evidence from KSE (Karachi Stock Exchange). International Knowledge Sharing Platform : Research Journal Of Finance And Accounting, 5(15). Retrieved from http:/www.iiste.org/journals/

HARGRAVE, M. (2019). How to Use the DuPont Analysis to Assess a Company's ROE. Retrieved from https://www.investopedia.com/terms/d/dupontanalysis.asp 